\title{
Hermeneutyka polskiej szkoły filmowej
}

Hermeneutics of the Polish film school

\author{
|| Marek Hendrykowski
Uniwersytet im. Adama Mickiewicza w Poznaniu
}

\begin{abstract}
The subject of the study is an attempt to reconsider the artistic achievements of the Polish film school, taken in terms of hermeneutics. The author questions the hitherto shots of this phenomenon aiming at reorienting the circular way of its recognition and proposing his own view.
\end{abstract}

Key words: hermeneutics, Polish Film School, cinema, art of moving pictures, author, audience

Streszczenie: Przedmiotem studium jest próba ponownego rozpoznania artystycznego dorobku polskiej szkoły filmowej, podjęta w kategoriach hermeneutyki. Autor kwestionuje dotychczasowe ujęcia tego zjawiska, zmierzając do przeorientowania obiegowego sposobu jego ujmowania i proponując własne spojrzenie.

Słowa kluczowe: hermenautyka, polska szkoła filmowa, kino, sztuka ruchomych obrazów, autor, publiczność

$\mathrm{Na}$ przestrzeni ponad studwudziestoletnich dziejów naszej kinematografii i w całej historii rodzimej sztuki filmowej nie było dotąd zjawiska równie ważnego, jak to, które określa się umownie mianem: polska szkoła filmowa. Mowa nie tylko o jej znaczeniu lokalnym, lecz także - co warto mocno wyeksponować - o wizerunku zewnętrznym polskiego kina, które w tamtym czasie zyskało dzięki znakomitym filmom Wajdy, Munka, Kawalerowicza, Hasa, Różewicza, Lenicy, Konwickiego czy Morgensterna międzynarodowy rozgłos i światowy prestiż.

Owszem, kino polskie sięgało wtedy po najwyższe laury na najbardziej prestiżowych festiwalach filmowych w Cannes, Wenecji, San Sebastian, Edynburgu czy Mar del Plata. Kinomani całego świata znali Kanał, Popiół i diament, Pociag i Matkę Joannę od Aniołów. Niekończąca się polemiczna debata wokół ekranizacji Popiołów osiągnęła skalę, która nigdy potem nie była udziałem żadnego z polskich filmów. Sceptycyzm poznawczy nakazuje 
jednak powątpiewać, czy istotnie $\mathrm{w}$ pełni zdajemy sobie sprawę, czym naprawdę było wówczas unikatowe zjawisko zwane polską szkołą filmową i jak z dzisiejszej perspektywy przedstawia się jego ówczesna wartość artystyczna, socjokulturowa i psychospołeczna. Warto może też zastanowić się i nad tym, czy m.in. historyczno-polityczne uwikłania oraz zależności od „Wschodu” - paradoksalnie - nie były jednymi z impulsów powstania tego niepowtarzalnego filmowego fenomenu.

Aby zrozumieć sens zajmowania się hermeneutyką polskiej szkoły filmowej, trzeba najpierw przyjąć założenie, iż ciągle nie wiemy i nie jest całkiem jasne i oczywiste, czym formacja ta była ówcześnie, jak zmieniała się w kilkunastoletnim przebiegu własnego rozwoju, i co naprawdę istotnego po sobie zostawiła. Wiemy już na podstawie serii wcześniejszych historycznofilmowych analiz i studiów, że projekt w nią wpisany nie był czymś jednoznacznym i skrystalizowanym ani w momencie inicjalnym (1954-1955), ani w latach rozkwitu (1956-1960), ani też później w fazie dojrzałej (Jak być kochana, Przy torze kolejowym, Popioły, Salto, Faraon, Szyfry, Westerplatte) czy w stadium jej zmierzchu, które przypada na przełom lat 60. i 70., uwieńczony Krajobrazem po bitwie, Jak daleko stad, jak blisko i Weselem.

To samo o przyrodzonej „nieoczywistości” terminu polska szkoła filmowa można powiedzieć post factum, ilekroć niczym widmo powracała ona - bardziej już jako znaczący artefakt historycznofilmowy - stając się obiektem wielokrotnych polemik i ostrych sporów. Widać to wyraźnie zarówno w fazie partyjnego „wygaszania” szkoły polskiej (Uchwała Sekretariatu KC PZPR z czerwca 1960 roku), jak i w powracających kilkakrotnie sporach i polemikach, które trwały jeszcze długo potem, przez całą dekadę lat 70.

Przez jednych oceniana bardzo wysoko, opisywana w perspektywie rozbudzonych nadziei społeczno-artystycznych rodzimego kina, przez drugich potępiana za to, co chwalili i doceniali ci pierwsi. Emocje budziły już pierwsze filmy spod znaku tej formacji: Kanał, Eroica, Pętla, Pigułki dla Aurelii, Popiól i diament, Lotna, Zezowate szczęście. Tak miało pozostać również w okresie późniejszym, ilekroć pojawiały się próby rekapitulacji dokonań twórczych tej formacji i jej doniosłego znaczenia dla rozwoju rodzimej sztuki filmowej.

Namiętny konflikt, jaki rozgorzał w połowie lat 60. wokół polskiej szkoły filmowej, miał w gruncie rzeczy charakter pretekstowy, stanowiąc pole zastępcze o wiele rozleglejszego sporu o Polskę i definicję polskości. Nie chodziło zatem stricte o szkołę polską, lecz o to, co formacja ta ucieleśniała i reprezentowała $\mathrm{w}$ artystycznych dążeniach. Ona sama, wyrywana przez polemistów z macierzystego kontekstu i odzierana z bogactwa projektowanych i posiadanych znaczeń, niejednokrotnie bardziej przypominała stracha na wróble, albo ćwiczebną atrapę na strzelnicy, niż realny byt artystyczny.

Dochodzi do tego następna trudność poznawcza, którą pierwszy trafnie rozpoznał Aleksander Jackiewicz. Idzie o mnogość autorskich wersji tego fenomenu. Inaczej rysuje się obraz polskiej szkoły filmowej, kiedy w jej 
centrum staje w roli lidera Andrzej Wajda (tak bywało i bywa najczęściej); z kolei inaczej wypadnie jej charakterystyka, gdy alternatywny akcent całościowego obrazu zostanie położony na postać Andrzeja Munka; jeszcze inaczej, gdy uwagę skupimy przede wszystkim na Hasie, Różewiczu czy Konwickim. W zależności od tego, na kogo skierujemy spojrzenie i wiązkę światła, komu przypadnie fokus i kogo szczególnie wyróżnimy, szkoła polska jako pojęcie zbiorcze i wieloautorskie będzie odpowiednio do tego zmieniać swój image i złożony charakter.

Nie znaczy to, że mamy do czynienia z pojęciem rozmytym i migotliwym. Znaczy natomiast, iż w grę wchodzi w tym przypadku niezwykłe bogactwo autorów, współautorów, poszukiwań i dzieł. A skoro tak, nasuwa się w tym miejscu zasadne pytanie o wewnętrzną spoistość wieloosobowego twórczego działania, która pozwala mówić o istnieniu formacji.

Rodzaj hermeneutycznej mądrości, w jaki wyposażyła nas polska szkoła filmowa, polega na posługiwaniu się przez jej twórców szczególnym rodzajem racjonalności dotyczącej działania. Działania w konkretnej sytuacji, w określonych, zmiennych okolicznościach, w ramach dostępnych możliwości i istniejących ograniczeń: w ciągłym rozpostarciu między tym, co $\mathrm{w}$ danym hic et nunc było niemożliwe do urzeczywistnienia (nieprzedstawialne z powodu przemożnej presji cenzury), a tym, co możliwe do ukazania i wyrażenia na ekranie: na granicy i w konfrontacji z wykluczonym.

Przy czym szkoła polska nie była klubem nawiedzonych szalonych filmowców. Wszelkie jej poszczególne zamysły i indywidualne dokonania łączą w sobie artystyczną ambicję i odwagę z rozsądnym (racjonalnym) rozwiązywaniem konkretnych problemów i wyzwań. Z drugiej strony jednak, zauważalna różnica z Arystotelesowskim ujęciem rozsądku i człowieka rozsądnego polega na tym, iż - w przeciwieństwie do niego - twórcy polskiej szkoły filmowej niezmiernie wiele uwagi poświęcali namysłowi nad rzeczami i działaniami, których nie można dokonać, mimo wszystko próbując usilnie osiągnąć i zrealizować w swoich filmach to, co wydawało się a priori wykluczone i nieosiągalne.

W pierwszej chwili przerzucenie pomostu między dążeniami XX-wiecznej formacji ideowo-artystycznej w sztuce filmowej a szóstą księgą Etyki nikomachejskiej Stagiryty, w której filozof roztrząsa związki między sophią jako mądrością teoretyczną, rozsądkiem jako mądrością praktyczną a techne jako wiedzą na temat praktyki tworzenia i wytwarzania (Arystoteles 1996), może wydać się zabiegiem tyleż sztucznym, co nader ryzykownym intelektualnie. Tak jednak nie jest.

Mądrość praktyczna szkoły polskiej, w powiązaniu z celami twórczymi osiąganymi poprzez działanie, łączy w sobie phronesis z wydatnie poszerzoną perspektywą „należytego zrozumienia wszystkich własnych spraw” (określenie samego Arystotelesa) i wiedzą o tym, jak zamierzone cele w praktyce urzeczywistnić. Dzięki niej filmowcy tej formacji zdołali w okresie jej istnienia urzeczywistnić aż tyle ambitnych projektów i nakręcić 
zdumiewająco wiele ważnych dzieł: począwszy od Człowieka na torze, a skończywszy na Jak daleko stąd, jak blisko i Weselu.

Ci, którzy po latach surowo oceniają dokonania twórców polskiej szkoły filmowej, dopatrując się w nich jedynie półprawd, kłamstw, uników, przemilczeń i ewidentnych kompromisów zawieranych z panującą ideologią i władzą, zdają się całkiem zapominać o historycznym i politycznym kontekście, w jakim ona funkcjonowała. Te wspaniałe filmy nie powstawały w warunkach absolutnej wolności twórczej, lecz były kręcone w przyziemnych realiach powszechnej niemożności, które tę upragnioną wolność i ściśle związane z nią twórcze dążenia wielorako ograniczały. W tej sytuacji kompromis stanowił codzienny modus vivendi filmowców i modus operandi środowiska filmowego, a problemem zasadniczym stawał się nie sam kompromis, lecz jego etyczne granice.

Szkołę polską charakteryzuje permanentny konflikt między założonym a osiągniętym, między osobistym dążeniem filmowca a finalnym efektem ekranowym, między niemożliwym a możliwym. Napięcie to obejmuje również swym zasięgiem, o czym na ogół się nie pamięta, szeroko pojętą praktykę twórczą, a w jej ramach zakulisową sferę produkcji i realizacji tych filmów. Arystotelesowska techne (twórcze „umiem” oraz „potrafię”), z istoty swej przypisana wszelkim wariantom i postaciom tworzenia, spotyka się tutaj i łączy z phronesis jako działaniem roztropnym i etycznym.

Rola techne w przypadku szeregu wybitnych dzieł polskiej szkoły filmowej zyskuje swój pierwszorzędnie ważny status oraz niezbywalny udział. Na opisanych niegdyś przeze mnie szczegółowo przykładach Eroiki i Popiołu i diamentu (Hendrykowski 2008, Hendrykowski 2011), ale także na przykładzie wielu innych filmów: Kanał, Pętla, Ostatni dzień lata, Pociag, Świadectwo urodzenia, Nikt nie woła, Rękopis znaleziony w Saragossie, Faraon, Jak daleko stąd, jak blisko, Wesele itp. - widać doskonale, jak wielkiego skoku dokonała i jak doniosłą rolę odegrała ta formacja w przeniesieniu naszej kinematografii z poziomu socrealistycznej manufaktury na budzący podziw, mistrzowski poziom światowego formatu profesjonalizmu twórczego w sferze: scenariopisarstwa, adaptacji, reżyserii, aktorstwa, sztuki operatorskiej, scenografii etc.

Konflikt, o którym wyżej mowa, nie ogranicza się jedynie do sfery zmagań zewnętrznych, rozgrywających się wokół urzeczywistnianego z wielkim trudem projektu twórczego. Przenosi się on również pośrednio na świat wewnętrzny i bohaterów tych dzieł. Złożoność ich struktur i wizerunków wywiera przemożny wpływ na komunikowanie. Sprawia bowiem, iż wielkie figury semantyczne zostają przez twórców wyposażone w poszerzoną pojemność znaczeniową. To z kolei powoduje, że twórczość filmowa: Andrzeja Munka, Andrzeja Wajdy, Jerzego Kawalerowicza, Wojciecha Jerzego Hasa, Stanisława Różewicza, Tadeusza Konwickiego, Stanisława Lenartowicza, Janusza Morgensterna, podobnie - poniekąd jak animacje Jana Lenicy - niesie z sobą różnorodny wyraz i zaskakujące bogactwo 
znaczenia. Wieloznaczność ta skłania badacza, by rozpatrywać ją i odczytywać w kategoriach swoistego zadania interpretacyjnego. Zadania, które domaga się zastosowania klucza hermeneutyki.

W pierwszym rzędzie dotyczy to złożoności konstrukcji postaci. Bohaterowie tych filmów (maszynista Orzechowski, Zadra, Korab, Kuba, Maciek Chełmicki, obrońcy Poczty Gdańskiej i Westerplatte, wdowa po Joczysie, Piszczyk, Bożek, Marta, Felicja, chłopiec-pacjent w Milczeniu, Rafał Olbromski, Krzysztof Cedro, książę Gintułt, Michcik, KowalskiMalinowski, Haratyk i inni) nie są tylko konwencjonalnym elementem ekranowego świata. Przypada im bowiem nieporównanie bardziej złożona rola medium. Odczuwamy ich obecność, oglądamy, wpatrujemy się i wsłuchujemy, jednocześnie odbierając oglądaną rzeczywistość poprzez nich: jako ich własną jej wersję, zsubiektywizowany audiowizualny ekwiwalent osobistego doświadczenia, będący artystycznym wyrazem przeżywania przez nich perypetii i dramatów otaczającego uniwersum.

Tak obmyślany sposób konstrukcji bohatera i taki modus narracji sprawia, że percypowana ekranowa rzeczywistość składa się z obrazów „cudzych”, wyraziście zindywidualizowanych i wyjątkowych, a równocześnie dziwnie znajomych widzowi. Znajomych, to znaczy będących - fragmentarycznie bądź w strukturze całości - artystyczną projekcją nie tylko czegoś indywidualnego, oryginalnego i niepowtarzalnego, jedynego w swoim rodzaju, lecz również - doniosłym echem wspólnego doświadczenia społecznego, stanowiącego ekranowy wyraz wspólnoty i pochodną zbiorowej egzystencji.

To ważny paradoks szkoły polskiej: nieustanna interferencja zachodząca pomiędzy tym, co unikatowe, a tym, co pozostaje nadal nieprzepracowanym doświadczeniem zbiorowym. Nie trzeba dodawać, iż zabieg ten koreluje i łączy w sobie wrażliwość artysty filmowego z oczekiwaną wrażliwością adresata filmu.

Z wyłożonych powyżej powodów kategorią o kluczowym znaczeniu dla zbioru dzieł polskiej szkoły filmowej okazuje się milczenie ${ }^{1}$. Milczenie dotyczące zarówno postaci ekranowych będących bohaterami (z epizodami włącznie), jak i kompatybilne względem niego milczenie autorów, którzy z konieczności unikają mówienia głośno, jawnie i wprost, licząc - niebezpodstawnie - na domyślność widzów. Cała bez wyjątku polska szkoła filmowa daje się metaforycznie opisać jako swoisty greps (list na zewnątrz) człowieka uwięzionego: zaszyfrowany komunikat zza muru milczenia. Polityczna i ideologiczna podległość Polski jest koniecznym/istotnym kontekstem do interpretacji fenomenu szkoły, który jednocześnie zostaje kapitalnie artystycznie przetworzony.

Milczenie - w sensie dosłownym i w przeniesieniu metaforycznym - stanowi niezmiernie istotne widmo, „ciemną materię" filmów polskiej szkoły

$1 \quad$ Na temat roli semantycznej milczenia zob. znakomite studium analityczne Izydory Dąmbskiej (Dąmbska 1973). 
filmowej. To milczenie zza grobu bohaterskiego maszynisty Orzechowskiego w Człowieku na torze i dosłowne milczenie małomównego Rumszy w Zimowym zmierzchu. Ale także uparte milczenie cierpiącego chłopca w filmie Kutza Milczenie i echo spraw nieprzebrzmiałych w niedocenionym dramacie Stanisława Różewicza Echo. To również widmo wszelkiego rodzaju podtekstów i aluzji w Kanale, Eroice, Popiele i diamencie, Zezowatym szczęściu, Matce Joannie od Aniołów i wielu innych dziełach spod znaku szkoły polskiej.

Oglądając te filmy, ma się nieustannie do czynienia z subwersywnym pasmem niedopowiedzeń i celowych niedomówień. Raz można wyrazić więcej, raz mniej, niekiedy przekaz zamienia się niemal w wymagający niełatwego odcyfrowania i umiejętnego odczytania palimpsest. Symbolicznego znaczenia nabiera w kontekście tych stwierdzeń wymowny tytuł filmu Hasa - Szyfry. Gatunek, a raczej odmiana gatunkowa, kameralnego dramatu współczesnego o tematyce okupacyjnej staje się tutaj wehikułem komunikowania z widownią.

Nie tylko Szyfry stawiają na wielopoziomową złożoność charakterystyki genologicznej. Gra prowadzona z gatunkiem dotyczy również licznych innych dzieł polskiej szkoły filmowej: począwszy od Człowieka na torze, Zimowego zmierzchu, Prawdziwego końca wielkiej wojny, Kanału i Eroiki aż po Westerplatte, Wszystko na sprzedaż, Słońce wschodzi raz na dzień, Krajobraz po bitwie, Jak daleko stad, jak blisko i Wesele. Grawitując w stronę kina dla wszystkich (stąd waga wykorzystanego gatunku filmowego jako medium porozumienia), ich autorzy rezygnowali jednak z pokusy drogi „na skróty”, zachowując zasadę unikania łatwej i uproszczonej charakterystyki bohaterów oraz wizji świata na ekranie.

Do przemyślenia zostaje w związku z tym coś jeszcze, a mianowicie kwestia pragmatyki komunikacyjnej dotyczącej ewentualności nieporozumienia (w pojęciu braku i jednocześnie wymogu porozumienia, które staje się zadaniem). Jak powiadał René Clair: „Widz też musi mieć talent”. Trudniej - znaczy tu pełniej i vice versa. Zamierzona enigmatyczność i zagadkowość filmowego wyrazu bowiem, choć utrudnia porozumienie, nie musi bynajmniej oznaczać zerwania procesu komunikacji. Twórczo użyte i umiejętnie wykorzystane przez artystę - staje się ono zaczynem dialogu. „Nie wiem” jest w nim ważniejsze i nieporównanie uczciwsze od niewzruszonej pewności zadufanego i chełpliwego „wiem”.

Nie chodzi bynajmniej o modną dzisiaj relatywność tego, co uchodzi za „prawdziwe”. Język (kod porozumienia) polskiej szkoły filmowej z wirtualnym odbiorcą serii jej dzieł z konieczności sięgał po metaforę, symbol, aluzję, eliptyczne niedopowiedzenie i w sposób niezmiernie efektywny posługiwał się wieloznacznością. W grę wchodził czytelny dla adresata filmowy szyfr. Nie było innego sposobu. Prawda (lub to, co skłonni jesteśmy za nią uważać, odnosząc ekranowy przekaz do przedstawionego w nim obrazu 
człowieka i świata) staje się w tym przypadku artystyczną funkcją jednostkowego i równocześnie zbiorowego doświadczenia.

Mówi się, że film jako dzieło jest metaforą życia. Jego sztuczność i fikcjonalność przeistacza się w kontakcie z widzem w coś wiarygodnego i prawdziwego. W szczególnie intensywny sposób przenośnia ta działa w odniesieniu do filmu o powstawaniu filmu. Bohater filmu Wajdy Wszystko na sprzedaż rozszczepia się na szereg postaci. Jest Aktorem, który odszedł na zawsze, i Reżyserem Andrzejem, który próbuje na nowo przywołać jego obecność. I wreszcie migotliwą wiązką rozproszonych, zatomizowanych wspomnień kręgu ludzi, którzy go osobiście znali i dla których był przez wszystkie przeżyte wspólnie lata kimś ważnym.

Podmiotowość i autorskość polskiej szkoły filmowej zawiera w sobie społeczną konstrukcję procesu komunikowania autora nie jako izolowanego indywiduum, lecz jako jednostki społecznej. Twórcy tej formacji są głęboko świadomi, iż film, kino i sztuka filmowa żyją dzięki życiu w społeczeństwie, zaś filmowiec - niczym szaman - posiada magiczną moc kreowania i wyjawiania ukrytych światów. Magiczną w swej istocie moc przedstawiania, nazywania ich, definiowania ich charakteru i urzeczywistniania na ekranie we wszechstronnym kontakcie i głębokim porozumieniu ze zbiorowością.

Stąd film - jako dzieło tworzone tyleż w imieniu własnym, co w imieniu zbiorowości - i autor zmierzają ku pewnej formie samoświadomości, dokonując swoistej redefinicji samych siebie. W taki sposób uprawiana - i tak pojęta - twórczość filmowa staje się pomnażaniem dobra wspólnego - specyficzną formą działania symbolicznego, wpisanego w pozaartystyczne procesy toczące się w życiu społecznym.

W tym sensie - nawet mając potężną władzę cenzurowania i dysponując jej rozlicznymi instancjami, narzędziami i metodami - prawdy osobiście doświadczonej i przeżytej, a następnie zapośredniczonej przez twórcę w dziele filmowym, nie da się całkiem zakłamać. Zdławienie przez władze partyjne szkoły polskiej w roku 1960 odebrało jej oddech, ale nie pozbawiło dalszego ciągu i możliwości autorskiej ekspresji.

Warto spojrzeć na polską szkołę filmową w kategoriach swoistej phronesis - dostrzegając w niej specyficzną postać/formę/wyraz/przejaw ambitnego współdziałania społeczno-artystycznego. Działanie to posiada zarówno swój wymiar indywidualny (dzieła poszczególnych autorów), jak i ściśle z nim połączony aspekt zbiorowy (korelacja współdziałania wielu współtwórców tych filmów). Takim właśnie twórczym działaniem społecznym w sensie phronesis jest również sam proces komunikowania poprzez film i powiadamiania za jego pośrednictwem adresata komunikatu o doniosłych sprawach w filmie poruszanych.

Hermeneutyczny klucz zastosowany w odniesieniu do opisywanego przez nas fenomenu, wychodząc od postawy sceptycznej, ma na celu wskazanie nowej perspektywy i rewizję dotychczasowego spojrzenia. Na przeszkodzie głębszemu odczytaniu znaczeń tych utworów w kontekście historycznej 
rewizji dokonań polskiej szkoły filmowej stoi bowiem od dawna zastygły i całkiem nieadekwatny wobec charakteru i zawartości jej dzieł sposób ich odczytywania. Jego podstawową wadę stanowi atomizacja przyjętego ujęcia jako skutek izolowanego traktowania poszczególnych twórców.

Z tego powodu szkoła polska przestaje być wieloznaczną i wieloautorską całością, którą niegdyś historycznie stanowiła. Poszczególne dzieła i ich konteksty nie stanowią już czytelnej części w ramach czytelnej całości. Zamiast żywej struktury historycznofilmowej otrzymujemy martwy inwentarz nazwisk i tytułów. Przestają się liczyć konkretne utwory, komunikaty; pojedynczy izolowany film gubi swój ogólniejszy sens jako artefakt i forma twórczego działania. Tracą znaczenie koincydencje, napięcia, szeregi, serie, toczone dyskursy, dynamika przemian i ciągłych przewartościowań dokonujących się w procesie historycznofilmowym.

Ani pojedyncze dzieła, ani ich twórcy w odniesieniu do charakterystyki tej formacji nie powinni być traktowani jako monady, samotne wyspy i odseparowane od siebie byty indywidualne. Indywidualizm twórczy okazuje się tu bowiem funkcją działania społecznego. A działanie to miało w dziełach szkoły polskiej z istoty swej charakter dialogowy, to znaczy wywołujący żywe echo toczonego publicznie dyskursu. Mowa tu nie tylko o dialogu twórcy z publicznością. Rozmawiali z sobą autorzy, rozmawiały ich filmy. Prawdziwym wyzwaniem badawczym staje się w związku z tym pytanie: ile jest Munka w Wajdzie, ich obu w Hasie i Lenartowiczu, ile Kanału w Eroice, Człowieka na torze w Zimowym zmierzchu, a Popiołu i diamentu w Nikt nie woła, w jaki sposób i w jakim celu Konwicki rewiduje i dekonstruuje mit Cybulskiego w kolejnych scenach Salta etc.

Wewnętrzną spoistość wszystkim tym utworom, poruszanym w nich tematomi różnorodności wykorzystanych stylów, nadaje po etyka d oświadczenia jako klucz do rozpoznania sensu podjętego i zrealizowanego działania artystycznego ${ }^{2}$. Powszechnie niegdyś czytelny, sens ów jest również możliwy do odczytania i zrozumiały dzisiaj, kiedy wiele z tych spraw i ukazanych dramatów wydaje się sprawami dla współczesnego widza odległymi i minionymi, a z kolei inne (np. Maciek Chełmicki jako przypadek żołnierza wyklętego albo nadal niewygasły spór o powstanie warszawskie) nabierają obecnie nieoczekiwanie aktualnego wydźwięku.

Kino polskiej szkoły filmowej w jego najlepszym wydaniu (mowa o filmach takich, jak: Człowiek na torze, Kanał, Eroica, Popiół i diament, Krzyż Walecznych, Zezowate szczęście, Zaduszki, Nikt nie woła, ale również Jak być kochana, Popioły, Salto, Ręce do góry, Słońce wschodzi raz na dzień, Krajobraz po bitwie, Jak daleko stą, jak blisko, Wesele i szeregu innych) pozostaje przekazem wrażliwym na empirię, programowo nieufnym wobec łatwych rozwiązań i uproszczonych przedstawień.

Jeśli w filmach szkoły polskiej - od Człowieka na torze po Wesele wziąć pod uwagę stałą obecność takich czynników przekazu, jak: milczenie,

Na temat kategorii doświadczenia zob. Nycz 2012. 
niedomówienie, aluzja, peryfraza, elipsa, parabola, metafora i symbol owa jego komunikowana niedookreśloność prowadzi do wyciągnięcia bardziej generalnego wniosku. Otóż w dziełach tych mamy do czynienia z niezwykle kunsztownie uprawianą i umiejętnie rozwijaną dyskrecją znaku. Niemożność otwartego wyrażenia pewnych treści, powiązana z jego potrzebą, uruchomiła u twórców tych dzieł specyficzny rodzaj wyobraźni naznaczony przedstawianiem nie wprost, subwersywnie i domyślnie.

Jeśli się nie zna realiów historycznofilmowego kontekstu i okoliczności, w jakich filmy te powstawały, można ulec mylnemu wrażeniu, że obcujemy z ciągiem nieustannie robionych uników. Nic podobnego. Stawiając czoła rozmaitym niemożnościom, nakazom i zakazom, polska szkoła filmowa we wszelkich jej poczynaniach, ograniczana cenzuralnie, ideologicznie i politycznie, stawiała w ekranowym przekazie na domyślność wirtualnego adresata.

Widz ów nie miał być biernym konsumentem podsuwanych znaczeń, lecz aktywnym odkrywcą i partnerem w filmowym procesie porozumienia z autorem. Przekaz filmowy na tym nie tracił, lecz - paradoksalnie - zyskiwał artystycznie. Znak i obraz w utworach szkoły polskiej stawał się dzięki tym nieustannie ponawianym staraniom znakiem i obrazem semantycznie o wiele pojemniejszym i głębszym w swym wyrazie.

Refleksja powyższa rozszerza się dalej, rozciągając na kreowany przez poszczególnych twórców tej formacji model świata przedstawionego. On także stanowi nośną metaforę, przerzucając symboliczny pomost między brzegiem indywidualnej ekspresji twórczej artysty a przeciwległym brzegiem wspólnych doświadczeń zbiorowości. To, co indywidualne, osobiste i intymne, niepostrzeżenie przechodzi i łączy się z tym, co powszechne i zbiorowe, znosząc dychotomiczny podział między jednostkowym a społecznym. Stąd, poprzez wykreowany na ekranie specyficzny wieloświat ukazywanych uczuć i myśli, kino spod znaku szkoły polskiej integruje, a nie dzieli miliony swoich adresatów.

Widać w tym - godną szacunku z punktu widzenia badacza dziejów polskiego filmu - konsekwencję dążenia i działania artystycznego czołowych reprezentantów tamtej formacji. W ówczesnych warunkach realizacji i okolicznościach cenzuralnych nakręcono tyle, ile było możliwe ${ }^{3}$. Zasadniczym celem wpisanego w to działanie projektu ideowo-artystycznego było przeformułowanie zadań kina zmierzające do przebudowy świadomości zbiorowej. Podawanie w wątpliwość tego, co wydaje się oczywiste, zakwestionowanie obiegowego sposobu myślenia, z jakim mamy tu do czynienia, miało skłaniać widza do stawiania ważnych pytań, które mogą prowadzić do nowych rozpoznań i do istotnego przewartościowania zastygłych zbiorowych wyobrażeń.

$3 \quad$ O projektach filmów spod znaku szkoły polskiej wówczas z różnych względów niezrealizowanych zob. Lubelski 2012. 


\section{Bibliografia:}

Arystoteles, 1996, Etyka nikomachejska, Etyka wielka, Etyka eudemejska.

O cnotach $i$ wadach, Gromska D. (przeł.), Warszawa.

Dąmbska Izydora, 1973, O funkcjach semiotycznych milczenia, w: Znaki i myśli, Warszawa.

Hendrykowski Marek, 2008, Popiół i diament, Seria Klasyka Kina/Classics of Cinema, Poznań.

Hendrykowski Marek, 2011, Eroico, Seria Klasyka Kina/Classics of Cinema, Poznań.

Lubelski Tadeusz, 2012, Niebyła historia kina PRL, Kraków.

Nycz Ryszard, 2012, Poetyka doświadczenia. Teoria - nowoczesność - literatura, Warszawa.

\section{O Autorze:}

Marek Hendrykowski, filmoznawca, badacz kultury współczesnej, profesor zwyczajny w Instytucie Filmu, Mediów i Sztuk Audiowizualnych UAM w Poznaniu. Członek Stowarzyszenia Autorów ZAiKS, Polskiej Akademii Filmowej i Europejskiej Akademii Filmowej (EFA). Autor książek: Semiotyka ruchomych obrazów (2015), Współczesna adaptacja filmowa (2015), Proksemika (2016), News. Antropologia - poetyka - kultura (2017), Semiotyka twarzy (2017), Drugie wejrzenie. Analizy i interpretacje (2018), Aktor i aktorstwo w filmie (2018). 